\title{
Оптимізація фізичної працездатності та рухової підготовленості школярів у процесі секційних занять волейболом
}

\author{
Ю. М. Андрійчук, В. В. Чижик
}

Луцький інститут розвитку людини Університету «Україна», Луцьк, Україна

\begin{abstract}
Резюме. Изучали влияние секционных занятий волейболом, направленных на оптимизацию двигательного развития и физической работоспособности, на организм ребят 14-16 лет. Предлагаемая программа секционных занятий волейболом является эффективным средством функционального, двигательного развития и увеличения физической работоспособности.
\end{abstract}

Ключевые слова: физическая работоспособность, двигательное развитие, волейболисты.

Summary. The influence of special volleyball classes aimed at optimizing motor development and physical performance on the body of 14-16 years old boys was studied. Proposed program of volleyball classes proved to be an effective mean to develop functional and motor abilities, and increase physical performance.

Key words: physical performance, motor development, volleyball.

Постановка проблеми. Аналіз останніх досліджень і публікацій. Однією з актуальних проблем спортивної медицини та фрізіології $\epsilon$ вивчення впливу фрізичних навантажень на організм дітей в умовах секційних занять спортом. Спортивні аспекти тренування у волейболі широко розроблені, але оздоровчий вплив цих занять на фрізичний розвиток школярів вивчений недостатньо.

Тренувальні заняття в секціях з волейболу повністю або частково орієнтовані на спорт вищих досягнень $[1,2,4]$. У деяких працях вивчались розвиток та контроль спеціальної витривалості у юних волейболістів [6], швидкісно-силова підготовленість волейболістів високої кваліфікації [2, 11], розвиток рухових здібностей та антропометричних даних юних волейболістів $[9,13]$. Проте питання оптимізації рухового розвитку та фрізичної працездатності школярів у процесі секційних занять волейболом практично не розглядались. На етапі загальної базової підготовки та переходу до спеціальної базової потрібно сформувати попередній функціональний резерв, який би став буфером, що пом'якшує гострий вплив тренувальних навантажень. [4, 5]. На думку авторів $[4,5]$, подальше спортивне вдосконалення без забезпечення загальної функціональної базової підготовки неможливе. Перехід до ранніх спеціалізованих навантажень у віці 14-16 років, хоча і приводить до росту результатів протягом двохтрьох років, у подальшому стає неефективним
[8]. Заняття у секціях з видів спорту необхідно розглядати як можливість отримати оптимальний об'єм рухового навантаження, що потрібен для нормального функціонування організму, його росту та розвитку на фоні росту (підвищення) профресійної майстерності [8].

Проведення секційних занять у школі передусім повинне мати оздоровчу мету й вимагає використання таких фрізичних вправ, які передбачають велику кількість учасників, оптимальну інтенсивність, регульовану в часі тривалість, велику моторну щільність і обмежене місце проведення. Вирішенню цієї проблеми сприятиме впровадження у практику фрізичного виховання школярів секційних занять $з$ волейболу. Такий підхід потребує використання найбільш ефективних науково обгрунтованих методик, спрямованих на оздоровлення, підвищення фрізичної підготовленості та ффізичної працездатності школярів та врахування індивідуальних особливостей росту та розвитку високорослих школярів. Заняття тільки тоді матимуть високий оздоровчий і розвиваючий вплив, коли будуть враховуватись морфоофункціональні особливості розвитку дітей і підлітків [5]. У зв'язку з цим нами було розроблено експериментальну програму секційних занять волейболом, що направлена на оптимізацію морфофрункціонального, рухового розвитку та фрізичної працездатності школярів 14-16 років.

Роботу виконано згідно зі Зведеним планом науково-дослідної роботи у сфрері фрізичної 
культури і спорту на 2006-2010 рр. Міністерства України у справах сім'ї, молоді та спорту за темою 3.2.7.1 п «Фізична працездатність та її сомато-вегетативне і моторне забезпечення у різних контингентів дітей і підлітків» (номер держреєстрації 0107U001186).

Мета роботи - вивчити вплив секційних занять волейболом, спрямованих на оптимізацію морфофрункціонального, рухового розвитку та фрізичної працездатності на організм хлопців 14-16 років.

Методи та організація дослідження. Фізична підготовленість школярів вивчалась за результатами Державних тестів [7] та системи тестів EUROFIT [15]. Використовували такі методи тестування рівня фрізичної підготовленості підлітків.

1. Тест "Сила кисті» виконувався за стандартною методикою динамометрії за допомогою динамометра ДК-60. Вимірювання повторювали три рази, фріксували найкращий результат у кілограмах.

2. Тест "УтримуВання тіла на перекладині»: з положення «вис на перекладині на прямих руках», зігнути руки в ліктьових суглобах і торкнутись підборіддям перекладини. Оцінка тесту: час утримування школяра на перекладині (у секундах).

3. Тест «Стрибок у довжину з місия» робився у три спроби, зараховувалась краща.

4. Тест «Піднімання тулуба в сід з положення лежачи на спині» - для вимірювання динамічної силової витривалості м'язів тулуба. Протягом 30 с потрібно зробити максимальне число повторень. Оцінюється число повних циклів (лягти - встати) за 30 с.

5. Тест «Рухливість у кульшовому суглобі» використовували для вимірювання гнучкості. Він полягав у тому, що досліджуваний, згинаючись у кульшовому суглобі, підсовував руки вперед, поклавши їх на дошку і переміщуючи лінійку. Результат тесту оцінювався у сантиметрах.

6. Тест «ЧоВникоВий біг» - для тестування спритності $(10 \times 5$ м) - виконували у вигляді ривка на максимальній швидкості 3 високого старту з поворотом на обмежувальних лініях. Оцінка: час виконання п'яти повних циклів (туди і назад) в секундах.

7. Тест на рівновагу "Фламінго» застосовувався для вимірювання статичної рівноваги і полягав у балансуванні на одній нозі на підставці певного розміру. Оцінка: кількість спроб, які школяр затратив на те, щоб зберегти стійке балансування на опорі протягом 1 хв.

8. Тест "Частота постуку८ань» - для вимірювання швидкості руху кінцівки за часом, потрібним для 25 циклів торкання двох площадок долонею - виконували два рази, і в залік йшов кращий результат тесту (у секундах).

9. Субмаксимальний тест $\mathrm{PWC}_{170}$ - для визначення фрізичної працездатності та розрахунку максимального споживання кисню.

10. Комп'ютерна система «Діагност - 1» для встановлення латентного періоду рухової реакції на звук і світло (розробник Макаренко М. В.). У всіх дослідах латентні періоди реакції визначали протягом трьох спроб з наступним обчисленням середнього арифметичного значення.

Функціональні дослідження проводились на базі лабораторії функціональної діагностики та фрізичної реабілітації Луцького інституту розвитку людини Університету «Україна».

Запропоновану програму тренувальних занять розробляли з урахуванням існуючих напрацювань [1] та розраховували на один навчальний рік - 3 вересня по травень, або 35 тижнів (204 год - по 6 год - тиж. ${ }^{-1}$ ). Окреме тренувальне заняття тривало в середньому 80-130 хв. Цілеспрямований вплив на «відстаючі» рухові здібності проводився на кожному тренувальному занятті (35-40 хв) і мав назву «блок-корекція». Для покращення фрізичної працездатності застосовували початкову гру та інші види рухової діяльності з елементами волейболу, які давали можливість виконання короткочасної роботи 3 високою інтенсивністю і нетривалими паузами відпочинку [10]. При тренувальних заняттях було враховано такі положення: використовували фрізичні вправи різнобічного спрямування із залученням до роботи великих м'язових груп, спрямованих на підвищення аеробних можливостей школярів та переважаючий вплив на «відстаючі» рухові здібності. Заняття проводили три-чотири на тиждень; тривалість часу на розвиток аеробних можливостей на занятті становила 15-20 хв, розвиток швидкості реакції - 8-10 хв, розвиток гнучкості - 7-10 хв; інтенсивність занять за частотою серцевих скорочень була в діапазоні 120-150 уд $\cdot \mathrm{XB}^{-1}$; тривалість заняття 80-130 хв. Заняття за експериментальною програмою проводили на базі експериментального майданчика НВО-ДНЗ-ЗОШ № 20 м. Луцька. У формувальному педагогічному експерименті взяли участь 190 школярів (14-, 15- та 16-річних), що займаються волейболом, зі спортивним стажем від одного до трьох років. Контрольна група - 98 юнаків, експериментальна -92.

Результати дослідження та їх обговорення. Ефективність програми оптимізації морфофункціонального, рухового розвитку та фрізичної працездатності хлопців 14-16 років в процесі 
ТАБЛИЦЯ 1 - Результати динаміки показників рухового розвитку юних волейболістів у формувальному педагогічному експерименті

\begin{tabular}{|c|c|c|c|c|c|c|c|}
\hline \multirow{3}{*}{ Тест } & \multirow{3}{*}{ Рухові здібності } & \multicolumn{2}{|c|}{14 років } & \multicolumn{2}{|c|}{15 років } & \multicolumn{2}{|c|}{16 років } \\
\hline & & к & E & К & E & $\mathbf{R}$ & E \\
\hline & & $n=32$ & $n=32$ & $n=30$ & $n=30$ & $n=36$ & $n=30$ \\
\hline «Сила кисті» & $\begin{array}{l}\text { Силові здібності, } \\
\text { кг } \cdot \kappa^{-1} \text { маси тіла }\end{array}$ & $0,53 \pm 0,01$ & $0,54 \pm 0,01$ & $0,53 \pm 0,01$ & $0,57 \pm 0,08^{*}$ & $0,59 \pm 0,02$ & $0,63 \pm 0,01^{*}$ \\
\hline \begin{tabular}{|l|} 
«Рухливість у куль- \\
шовому суглобі»
\end{tabular} & Гнучкість, см & $20,25 \pm 0,36$ & $23,27 \pm 0,37^{\star * *}$ & $19,07 \pm 0,84$ & $23,73 \pm 0,56^{\star * *}$ & $17,33 \pm 1,17$ & $22,03 \pm 0,12^{\star \star \star}$ \\
\hline $\begin{array}{l}\text { «Стрибок у довжину } \\
\text { 3 місця» }\end{array}$ & $\begin{array}{l}\text { Швидкісна сила } \\
\text { (вибухова), см }\end{array}$ & $186,50 \pm 3,57$ & $187,75 \pm 3,49$ & $219,80 \pm 3,60$ & $220,77 \pm 3,34$ & $227,89 \pm 4,93$ & $233,16 \pm 4,02$ \\
\hline \begin{tabular}{|l} 
«Піднімання тулуба \\
в сід із положення \\
лежачи на спині» \\
\end{tabular} & \begin{tabular}{|l|} 
Динамічна силова \\
витривалість, \\
разів за 30 с \\
\end{tabular} & $30,00 \pm 0,60$ & $31,59 \pm 0,50^{*}$ & $32,87 \pm 1,20$ & $36,30 \pm 0,72^{*}$ & $30,61 \pm 0,50$ & $33,84 \pm 0,63^{* * *}$ \\
\hline \begin{tabular}{|l|} 
«тримування тіла \\
на перекладині» 3 \\
положення «вис на \\
зігнутих руках» \\
\end{tabular} & $\begin{array}{l}\text { Статична силова } \\
\text { витривалість, с }\end{array}$ & $26,99 \pm 2,20$ & $28,06 \pm 1,67$ & $19,90 \pm 1,96$ & $25,72 \pm 1,53^{*}$ & $22,35 \pm 1,41$ & $27,88 \pm 1,25^{\star *}$ \\
\hline $\begin{array}{l}\text { «Човниковий біг» } \\
(10 \times 5 \text { м) }\end{array}$ & $\begin{array}{l}\text { Координаційні } \\
\text { здібності, с }\end{array}$ & $18,58 \pm 0,24$ & $17,85 \pm 0,25^{*}$ & $16,37 \pm 0,16$ & $16,08 \pm 0,10$ & $16,38 \pm 0,18$ & $16,15 \pm 0,16$ \\
\hline \begin{tabular}{|l|} 
«Фламінго» - ба- \\
лансування на одній \\
нозі на опорі \\
\end{tabular} & $\begin{array}{l}\text { Рівновага, } \\
\text { спроб } \cdot \mathrm{xB}^{-1}\end{array}$ & $9,75 \pm 0,44$ & $9,03 \pm 0,65$ & $10,40 \pm 0,63$ & $9,93 \pm 0,65$ & $10,72 \pm 0,53$ & $9,17 \pm 0,60$ \\
\hline $\begin{array}{l}\text { «Частота постуку- } \\
\text { вань» }\end{array}$ & $\begin{array}{l}\text { Швидкісні здіб- } \\
\text { ності, с }\end{array}$ & $12,65 \pm 0,15$ & $12,47 \pm 0,16$ & $11,60 \pm 0,22$ & $11,54 \pm 0,22$ & $12,68 \pm 0,99$ & $11,21 \pm 0,39$ \\
\hline $\begin{array}{l}\text { Система «Діаг- } \\
\text { ност-1» }\end{array}$ & \begin{tabular}{|l} 
Латентний час ру- \\
хової реакції, мс \\
на звук \\
на світло
\end{tabular} & $\begin{array}{l}216,38 \pm 2,67 \\
245,00 \pm 7,47\end{array}$ & $\mid \begin{array}{l}199,28 \pm 2,09^{* * *} \\
210,22 \pm 5,29^{* * *}\end{array}$ & $\begin{array}{l}191,23 \pm 2,97 \\
198,10 \pm 2,84\end{array}$ & $\begin{array}{l}192,50 \pm 2,92 \\
197,87 \pm 2,33\end{array}$ & $\begin{array}{l}193,22 \pm 3,21 \\
210,00 \pm 3,33\end{array}$ & $\begin{array}{l}183,25 \pm 2,00 \\
206,88 \pm 3,43\end{array}$ \\
\hline
\end{tabular}

* $p<0,05 ;{ }^{* *} p<0,01 ;{ }^{* *} p<0,001$ у порівнянні з контрольною групою.

секційних занять волейболом досліджувалась при порівнянні між собою показників контрольних та експериментальних груп наприкінці навчального року, а також отриманих показників - 3 даними інших авторів.

Розглянемо результати динаміки показників рухового розвитку юних волейболістів (табл. 1). Дослідження сили за показниками кистьової динамометрії виявили ії збільшення з віком як в контрольній (К), так і в експериментальній (Е) групах.

Абсолютні показники сили м'язів недостатньо інформативні, тому що обстежувані навіть одного віку відрізняються один від одного масою і будовою тіла. Тому для порівняльної оцінки використовують відносні показники сили, які вираховуються на одиницю маси тіла в процентах.

Відносні показники кистьової динамометрії в експериментальній групі були достовірно більшими в 15 та 16 років при $\mathrm{p}<0,05$.

Дослідження гнучкості за тестом «Рухливість у кульшовому суглобі» виявило статистично значиму різницю між обстеженими групами в усіх вікових періодах. У волейболістів експериментальної групи мали статистично значимо кращі показники у порівнянні з групою контролю при p $<0,001$ в 14, в 15 та 16 років.
При проведенні досліджень вибухової сили за тестом «Стрибок у довжину з місця» показано покращення ії з віком у волейболістів як контрольної, так і експериментальної груп, а також не виявлено статистично значимої різниці між показниками обстежених (див. табл. 1).

При вивченні силової витривалості за тестом «Піднімання тулуба в сід з положення лежачи за 30 с» було помічено значне покращення цього показника з віком в експериментальній групі зі статистично значимою різницею між показниками обстежених у всіх вікових групах при $\mathrm{p}<0,05, \mathrm{p}<0,05$ та $\mathrm{p}<0,001$ відповідно.

Дослідженнями силової витривалості за тестом «Утримування тіла на перекладині» 3 положення «вис на зігнутих руках» встановлено, що за даною руховою якістю спостерігалось значне покращення в експериментальній групі зі статистично значимою різницею між обстеженими волейболістами в 15 та 16 років при $\mathrm{p}<0,05$ та $\mathrm{p}<0,01$ відповідно.

При оцінюванні спритності за тестом «Човниковий біг» (10х5 м) виявлено, що дана рухова якість зростає з віком у волейболістів і контрольної, і експериментальної груп. Волейболісти експериментальної групи достовірно випереджали 

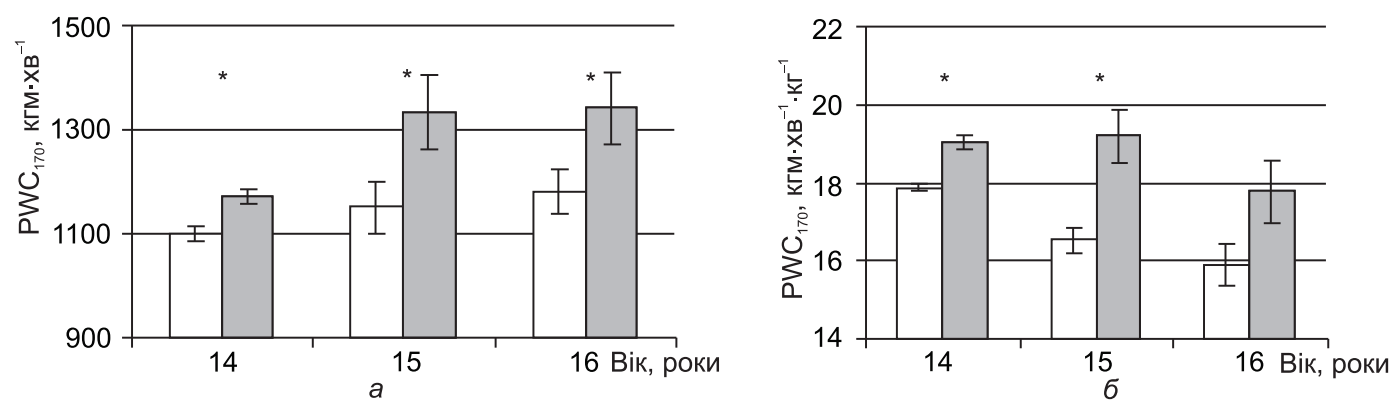

Рисунок 1 - Абсолютна (a) та відносна (б) фрізична працездатність за тестом $\mathrm{PWC}_{170}$ : $\square$ - контрольна, $\square-$ експериментальна.

за показниками своїх однолітків з контрольної групи в 14 років $(p<0,05)$ та значимо не відрізнялись від юних спортсменів в 15 та 16 років.

Дослідженнями рівноваги за тестом «Фламінго» - балансування на одній нозі на опорі встановлено, що за даною руховою якістю статистично значимої різниці між показниками обстежених не виявлено.

Вивчення швидкісних здібностей за тестом «Частота постукувань» показало, що за даною руховою якістю спостерігалось покращення з віком у волейболістів і контрольної, і експериментальної груп у 15 років при $\mathrm{p}<0,001$ і $\mathrm{p}<0,01$ відповідно, а також статистично значима різниця між показниками обстежених невелика.

Аналіз вихідних даних латентного часу рухової реакції на звук показав, що значимо менший час реагування був у хлопців-волейболістів експериментальної групи в 14 та 16 років при $\mathrm{p}<0,001$ та $\mathrm{p}<0,05$ відповідно, а між 15-річними юними волейболістами обох груп статистично достовірної різниці в часі простої реакції не виявлено.

При проведенні досліджень латентного часу рухової реакції на світло встановлено, що значимо менший час реагування був у хлопців-волейболістів експериментальної групи в 14 років при p < 0,001, а між 15- та 16-річними волейболістами не виявлено статистично достовірної різниці в часі простої реакції в обох групах.

Отже, вивчення рухової підготовленості 14-16-річних волейболістів експериментальної групи показало, що вони мали статистично значимо кращі показники кистьової динамометрії в 15 та 16 років при р <0,05, статичної витривалості - в 15 та 16 років при $\mathrm{p}<0,05$ та $\mathrm{p}<0,01$ відповідно, динамічної силової витривалості - в 14, 15 та 16 років при $\mathrm{p}<0,05$, $\mathrm{p}<0,05$ та $\mathrm{p}<0,001$ відповідно; гнучкості при p $<0,001$ - в 14, в 15 та 16 років; спритності в 14 років $(p<0,05)$, латентного часу рухової реакції на звук - в 14 та 16 років при $\mathrm{p}<0,001$ та $p<0,05$; латентного часу рухової реакції на світло - в 14 років при $\mathrm{p}<0,001$.
Для більш повного вивчення впливу експериментальної програми 3 волейболу як засобу оздоровлення необхідна комплексна оцінка фрізичної працездатності.

Дослідження абсолютної фрізичної працездатності за тестом $\mathrm{PWC}_{170}$ у волейболістів експериментальної групи показало, що вони мали статистично значимо кращі показники в порівнянні з групою контролю при р $<0,01$ в 14 років, при p $<0,05-$ в 15 років та при $\mathrm{p}<0,05-$ в 16 років (рис. 1$)^{\star}$.

При вивченні абсолютної фрізичної працездатності за тестом $\mathrm{PWC}_{170}$ встановлено такі показники $\left(\right.$ кгм $\left.\cdot \mathrm{XB}^{-1}\right)$ :

\begin{tabular}{lll}
\multicolumn{2}{c}{ Експериментальна група } & Контрольна група \\
14 років & $1171,61 \pm 16,44$ & $1105,05 \pm 13,88$ \\
15 років & $1334,15 \pm 72,69(\mathrm{p}<0,05)$ & $1150,16 \pm 50,41$ \\
16 років & $1341,45 \pm 66,06$ & $1181,23 \pm 41,53$
\end{tabular}

Отже, за показниками фрізичної працездатності волейболісти експериментальної групи достовірно випереджали в кожній віковій групі своїх однолітків.

При вивченні фізичної працездатності, віднесеної до маси тіла, встановлено, що волейболісти експериментальної групи достовірно випереджали за показниками своїх однолітків 3 контрольної групи в 14 та 15 років $(\mathrm{p}<0,001)$ та значимо не відрізнялись від юних спортсменів в 16 років (див. рис. 1, б). Цифррові значення відносного показника фрізичної працездатності були такими (кгм $\left.\cdot \mathrm{XB}^{-1} \cdot \mathrm{K}^{-1}\right)$ :

$\begin{array}{lcl} & \text { Експериментальна група } & \text { Контрольна група } \\ 14 \text { років } & 19,05 \pm 0,18 & 17,88 \pm 0,09 \\ 15 \text { років } & 19,19 \pm 0,68 & 16,52 \pm 0,34(\mathrm{p}<0,001) \\ 16 \text { років } & 17,78 \pm 0,79 & 15,90 \pm 0,53\end{array}$

Аналіз фрізичної працездатності за показником максимального споживання кисню $\dot{\mathrm{V}}_{2} \max$ волейболістів експериментальної групи показав, що

*Тут і далі достовірність різниці відповідно $\mathrm{p}<0,05, \mathrm{p}<0,01$, $\mathrm{p}<0,001$ 

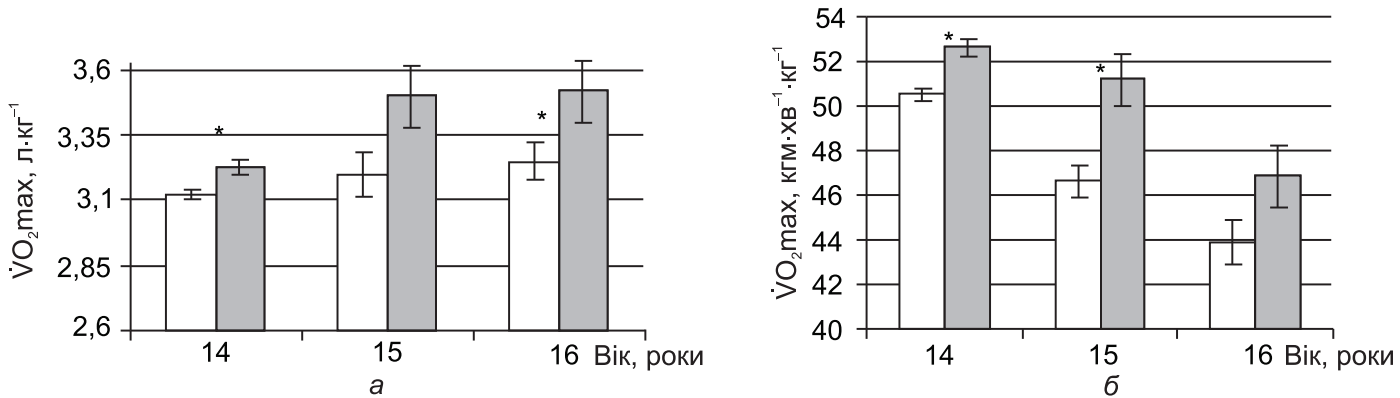

Рисунок 2 - Максимальне споживання кисню - абсолютне (а) та віднесене до маси тіла (б): $\square$ - контрольна, $\square-$ експериментальна

в них були достовірно кращі показники в порівнянні з контрольною групою в 14 та 16 років при p $<0,01$ та $p<0,05$ відповідно (рис. 2). Зазначимо, що в 15 років значимої різниці між показниками $\dot{\mathrm{V}} \mathrm{O}_{2}$ max в обстежених не спостерігалось.

У спортсменів експериментальної групи цифрове значення $\dot{\mathrm{V}} \mathrm{O}_{2} \max$ становило в 14 років $3,23 \pm 0,03 л \cdot$ хв$^{-1}$, в 15 років показник збільшується до величини $3,50 \pm 0,12$ ( $р<0,05)$, та в 16 років $-3,52 \pm 0,07 \pi \cdot \mathbf{x B}^{-1}$. Отримані нами в ході досліджень величини максимального споживання кисню у юних волейболістів дещо перевищують дані аналогічних досліджень [6] в 14 років $\left(2,34 \pm 0,29\right.$ л хв$\left.^{-1}\right)$ та практично співпадають із показниками в 15 та 16 років (3,59 0,24 л × хв $\left.{ }^{-1}\right)$.

Вивчення максимального споживання кисню на одиницю маси тіла волейболістів експериментальної групи показало, що в них були достовірно кращі показники в порівнянні 3 контрольною групою в 14 та 15 років при р $<0,001$ та $\mathrm{p}<0,01$ відповідно (див. рис. 2). Зазначимо, що в 16 років значимої різниці між показниками VัO max в обстежених не спостерігалось.

У спортсменів експериментальної групи цифрове значення $\dot{\mathrm{V}} \mathrm{O}_{2} \max$, віднесене до маси тіла, становило в 14 років 52,63 $\pm 0,039$ л $\cdot \mathrm{xв}^{-1} \cdot \mathrm{K}^{-1}$, в 15 років - 51,19 $\pm 1,16 л \cdot \mathrm{XB}^{-1} \cdot \mathrm{K}^{-1}$, та в 16 років - 46,88 $\pm 1,39$ л $\mathrm{XB}^{-1} \cdot \mathrm{K}^{-1}$.

Таким чином, кращі показники фрізичної працездатності (абсолютні і відносні) за тестом $\mathrm{PWC}_{170}$ виявлено у волейболістів експериментальної групи в порівняні 3 однолітками-волейболістами контрольної групи в 14, 15 та 16 років при $\mathrm{p}<0,01, \mathrm{p}<0,05$ та $\mathrm{p}<0,01$ відповідно. Подібні відмінності були і за показниками $\dot{\mathrm{V}} \mathrm{O}_{2} \max$, причому встановлено, що рівень максимального споживання кисню зростає з віком. Більші величини виявлено у волейболістів експериментальної групи в порівнянні з контрольною групою в 14 та 16 років ( $p<0,01$ та $p<0,05$ відповідно). Дослідження максимального споживання кисню на одиницю маси тіла волейболістів експериментальної групи показало, що в них були достовірно кращі показники, ніж у контрольній групі в 14 та 15 років при р $<0,001$ та $\mathrm{p}<0,01$ відповідно. Зазначимо, що з віком показник знижується і не має інформативного значення у системі контролю аеробної працездатності. Отримані дані вказують на покращення аеробних можливостей, яке на сьогодні розцінюється як збільшення кількісних показників здоров'я $[4,7,12,14]$.

Проведене дослідження довело: враховуючи особливості морфоорункціонального розвитку, рухової підготовленості і фрізичної працездатності школярів 14-16 років, можливо підвищити загальний рівень здоров'я і фрізичних можливостей. Реалізація експериментальної програми в комплексі з урахуванням функціональних та рухових особливостей дозволяє підвищити результативність педагогічного процесу, збільшити зацікавленість школярів у заняттях фрізичними вправами і, таким чином, сприяти фрормуванню у них оптимального фрізичного стану.

Виявлена нами тенденція підтверджує дані тієї групи дослідників, які спостерігали зменшення з віком відносних показників максимального споживання кисню [12]. Результатами нашої роботи доповнено дані В. А. Запорожанова зі співавт. [3], В. В. Чижика, В. П. Романюка [14] та інших стосовно морфофрнкціональних особливостей розвитку школярів, що займаються спортом, у різних вікових періодах.

Висновок. На основі отриманих нами результатів можна стверджувати, що запропонована програма оптимізації рухового розвитку та фрізичної працездатності хлопців 14-16 років у процесі секційних занять волейболом $\epsilon$ ефективним засобом рухового розвитку та збільшення фрізичної працездатності.

Перспективи подальших досліджень у даному напрямку можуть полягати у вивченні та врахуванні функціональних можливостей фрізіологічних систем, які забезпечують виконання м'язової роботи, в процесі планування тренувального навантаження для юних спортсменів інших вікових груп. 


\section{Література}

1. Волейбол: навчальна програма для ДЮСШ, СДЮШОР, ШВСМ та спеціалізованих навчальних закладів спортивного профілю / [укл. В. В. Туровський, М. О. Носко, О. В. Осадчий та ін.]; Мін-во України у справах сім'ї, молоді та спорту, Федерація волейболу України, Респ. науково-метод. кабінет. - К., 2009. - 138 с.

2. Гаркуша С. В. Біомеханічна корекція швидкісно-силової підготовленості волейболістів високої кваліфікації у передзмагальний період: дис... канд. наук з фіз. виховання і спорту: спец. 24.00.01 «Олімпійський і професійний спорт» / С. В. Гаркуша. - Х.: ХДАФК, 2005. - 177 с.

3. ЗапорожаноВ B. A. Комплексная система оценки перспективных возможностей юных спортсменов / В. А. Запорожанов, А. И. Кузьмин, Х. Созаньски // Наука в олимп. спорте. - 1994. - № 41. - С. 30-35.

4. Иорданская Ф. А. Мониторинг здоровья и функциональная подготовленность высококвалифицированных спортсменов в процессе учебно-тренировочной работы и соревновательной деятельности / Ф. А. Иорданская, М. С. Юдинцева. - М.: Сов. спорт, 2006. - 184 с.

5. Кашуба В. A. Технологии, сберегающие и корригирующие здоровье, в системе подготовки юных спортсменов / В. А. Кашуба, П. А. Яковенко, Т. А. Хабинец // Спорт. медицина. - 2008. - № 2. - С. 140-146.

6. Ковиун В. І. Розвиток та контроль спеціальної витривалості у юних волейболістів: автореф. дис. на здобуття наук. ступеня канд. наук з фріз. виховання і спорту: спец. 24.00.01 «Олімпійський і професійний спорт» / В. І. Ковцун. - Л., 2001. - 20 с.

7. КруцеВич Т. Ю. Методы исследования индивидуального здоровья детей и подростков в процессе фризического воспитания / Т. Ю. Круцевич. - К.: Олимп. лит., 1999. 231 c.

8. Никитушкин В. Г. Методы отбора в игровые виды спорта / В. Г. Никитушкин, В. П. Губа. - Смоленск: ИКА, 1998. - 284 с.

9. Носко М. О. Модельно-рейтингова оцінка фрізичної підготовленості юних волейболістів $10-12$ років на етапі початкового спортивного відбору / М. О. Носко, В. І. Синіговець // Педагогіка, психологія та мед.-біол. пробл. фріз. виховання і спорту. - 2001. - № 13. - С. 25-31.

10. Ровний A. C. Сенсорні механізми управління точнішими рухами людини / А. С. Ровний. - Х.: ХДІФК, 2001. - $220 \mathrm{c}$.

11. Синиговеи И. В. Скоростно-силовая подготовка волейболистов 15-17 лет с учетом игрового амплуа: автореф. дис. на соискание учен. степени канд. наук з физ. воспитания и спорту: спец. 24.00.01 «Олимпійський і професійний спорт» / И. В. Синиговец. - К.: Знання, 2007. $20 \mathrm{c.}$.

12. ТихВинский С. Б. Аэробная производительность // Детская спортивная медицина: рук. для врачей / С. Б. Тихвинский, Я. Н. Бобко; под ред. С. Б. Тихвинского. С. В. Хрущева [2-е изд.]. - М.: Медицина, 1991. - С. 273-281.

13. Хусино М. Развитие двигательных способностей юных волейболистов на этапе предварительной и специализированной базовой подготовки: автореф. дис. ... канд. пед. наук: спец. 24.00.01 «Олімпійський і професійний спорт» / М. Хусино. - НУФВСУ. - К., 1997. - 24 с.

14. Чижик В. В. Функціональна та рухова підготовка юного фрутболіста / В. В. Чижик, В. П. Романюк. - Луцьк: Твердиня, 2011. - 300 с.

15. Eurofit. Handbook of the EUROFIT tests of physical fitness. Council of Europe. - Strasbourg, 1993. - 75 p.
References

1. Volleyball: training program for DYuSSH, SDYuSHOR, SHVSM and specialized schools of sports profile / [eds. V. V. Turovskyi, M. O. Nosko, O. V. Osadchyi et al.] Ministry of Ukraine on affairs of Family, Youth and Sports, Volleyball Federation of Ukraine, Republican scientific and methodical department. - Kiev, 2009. - 138 p.

2. Garkusha S. V. Biomechanical correction of speedstrength training for top level volleyball players in the precompetition period: Diss. ... of Cand. of Sci. in physical education and sports, speciality 24.00.01 "Olympic and professional sports" / S. Garkusha. - Kharkiv: KhDAFK, 2005. - 177 p.

3. Zaporozhanov V. A. Comprehensive assessment of potential opportunities in young athletes / V. Zaporozhanov, A. Kuzmin, H. Sozanski // Science in Olympic sports. 1994. - N 41. - P. 30-35.

4. Jordanskaia $F$. A. Health monitoring and functional readiness of elite athletes during training and competitive activities / F. A. Jordanskaia, M. C. Yudintseva. - Moscow: Soviet Sport, 2006. - $184 \mathrm{p}$.

5. Kashuba V. A. Technologies, that saves and correct health, in the training of young athletes / V. A. Kashuba, P. A. Yakovenko, T. A. Khabinets // Sports medicine. 2008. - N 2. - P. 140-146.

6. Kovtsun V. I. Development and control of special endurance in young volleyball players: Abstract. dis. ... of Cand. of Sci. in physical education and sports, speciality 24.00.01 «Olympic and professional sport» / V. I. Kovtsun. Lviv, 2001. - $20 \mathrm{p}$.

7. Krutsevich T.Yu. Methods for assessment of individual health in children and adolescents in the course of physical education / T.Yu. Krutsevich. - Kiev: Olympic Literature, 1999. - $231 \mathrm{p}$.

8. Nikitushkin V. G. Methods of selection for team sports / V. G. Nikitushkin, V. P. Guba. - Smolensk: ICA, 1998. $284 \mathrm{p}$.

9. Nosko M.O. Model-rating evaluation of physical fitness in young volleyball players $10-12$ years old at the stage of initial selection for sports / M. O. Nosko, V. I. Synihovets // Pedagogics, psychology, medical-biological problems of physical training and sports. - 2001. - N 13. - P. 2531.

10. Rovnyi $A$. S. Sensory mechanisms involved in control of human precise movements / A. S. Rovnyi. - Kharkov: KhDIFK, 2001. - 220 p.

11. Sinigovets I.V. Speed-strength training of volleyball players 15-17 years-old considering the game position: Authoreferat of diss. ... Cand. of Sci. in physical education and sports, speciality: 24.00.01 «Olympic and professional sports» / I.V. Sinigovets. - Kiev: Znannja, 2007. - 20 p.

12. Tikhvinsky S. B. Aerobic capacity // Children's Sports Medicine: A Guide for Physicians / S. B. Tikhvinsky, Ya. N. Bobko; Ed. by S. B. Tikhvinsky, S. V. Khrushchev [2nd ed.] - Moscow: Medicine, 1991. - P. 273-281.

13. Husino M. Development of motor abilities of young volleyball players at the stage of preparatory and specialized basic training: Author. dis. ... Cand. of Sci. in pedagogy, speciality 24.00.01 «Olympic and professional sports» / M. Husino. - NUPESU. - Kiev, 1997. - 24 p.

14. Chyzhyk V. V. Functional and motor training for young footballer / V. V. Chyzhyk, V. P. Romaniuk. - Lutsk: Tverdynia, 2011. - $300 \mathrm{p}$.

15. Eurofit. Handbook of the EUROFIT Tests of Physical Fitness. Council of Europe. - Strasbourg, 1993. - 75 p. 